\title{
International winners for Japan's version of Nobel Prize
}

\section{Tokyo}

Winners of the Japan Prize, Japan's answer to the Nobel Prize, were announced last week. This year's prizes go to Dr Theodore H. Maiman, father of the laser, and to two noted agronomists, Drs Henry M. Beachell and Gurdev S. Khush. They will receive their awards on 14 April.

The prize, now in its third year, is worth Y50 million (US\$330,000) and is awarded in two fields each year by the Science and Technology Foundation of Japan. The foundation was set up in 1983 with a donation of Y3,000 million from Matsushita Electric Industrial Co. But plummeting interest rates in Japan have eaten into the foundation's earnings and Konosuke Matsushita, founder of the giant electronics company and president of the foundation, recently supplemented the funds with a personal contribution of $\mathrm{Y} 2,000$ million.

The prize is awarded to "persons recognized as having served the cause of peace and prosperity for mankind through original and outstanding achievements in
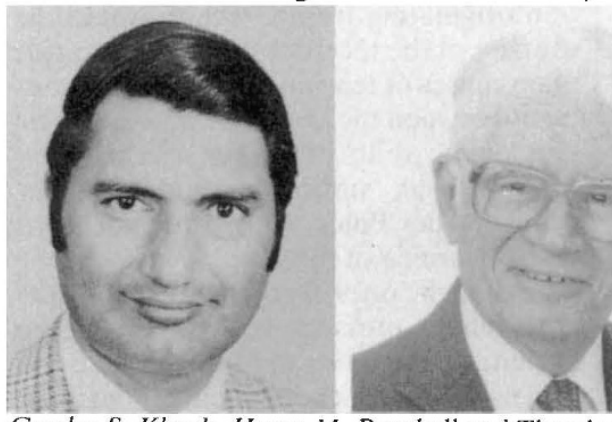

Gurdev S. Khush, Henry M. Beachell and Theodore H. Mainman science and technology", and is oriented towards the applied sciences

The two fields selected this year are improvements in biological functions and electro-optics. Maiman, a US citizen, won the prize in the latter category for his development of the ruby laser (Nature 187, 493-494; 1960), and Beachell and Khush share a prize for their development of superior rice strains, which brought about a 'green revolution' in Asia.

Beachell, a native of Nebraska in the United States, developed the IR8 variety of rice in 1966 at the International Rice Research Institute in the Philippines. The IR8 strain has high photosynthetic efficiency and brought a rapid increase in rice production in tropical and sub-tropical environments. Khush, from India, succeeded Beachell in 1972 as head of the institute's plant breeding department and through crossbreeding of 13 parent plants from six countries developed the IR36 strain, which, as well as having high yield, excels in resistance to disease, insects and adverse soil conditions. David Swinbanks

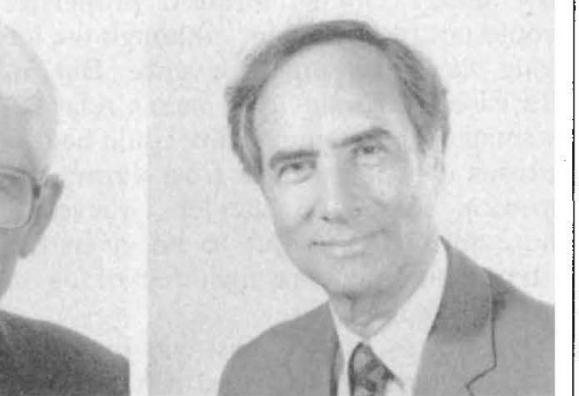
Indian technology missions told to hurry up Bangalore

Mr Rajiv Gandhi, the Indian Prime Minister, is dissatisfied at the tardy progress of the technology missions meant to provide safe drinking water, better communications, universal immunization and vaccination by 1990 and increasing oil seed production. He has therefore called for a more urgent approach from his ministers and he has directed the ministries and departments involved in programme implementation to keep him regularly formed of progressed. At a review meeting of the missions held early this year, Gandhi made it plain that "ministers and bureaucrats are equally responsible for the successful implementation of these missions and I will not spare anybody".

He went on to say that the objectives of each mission must be quickly achieved. "The objectives have to be specific, tangible and measurable. It is imperative that specific time-bound tasks are spelled out clearly and allotted to specific institutions for implementation."

Eleven pilot projects are under way in the drinking water mission in 15,000 villages. The communications mission is chiefly aimed at increasing the efficiency of telegram delivery in $\mathbf{5 0 0}$ towns and cities and the target for the telephone network is to bring down the fault rate from 35 per 100 telephones to 10 by 1990 .

The technology mission in vaccination and immunization plans to cover 92 million 1990. The chief diseases to be covered under this programme are polio, measles, tuberculosis, diphtheria, tetanus and typhoid. In oil seeds, the mission is hoping for an output of 24-26 million tonnes by the year 2000 , to which end work on development of high yielding varieties of groundnut, rapeseed, mustards, soyabean and sunflower has been intensified.

Radhakrishna Rao pregnant women and 82 million infants by

\section{Regulated misconduct}

Washington

THE National Science Foundation (NSF) plans to adopt formal rules for the regulation of misconduct by recipients of its grants. The rules, formally approved by a meeting of the National Science Board last week and published in draft form in the Federal Register for 10 February, are essentially the same as those in force at the National Institutes of Health. Misconduct is taken to include fabrication, falsification and plagiarism or similar deviations, failure to comply with regulations for the ethical treatment of human subjects and animals, and the breaking of laws applicable to research. According to Erich Bloch, director of NSF, only two cases of misconduct of this kind have come to light among recipients of NSF grants. Under the new procedures, which are open for comment until 13 April, first responsibility for investigating allegations of misconduct will lie with the recipient institution, in the light of which NSF will decide whether to hold an investigation of its own. There is a formal mechanism for appeal. Anonymous informants will be dealt with confidentially. Penalties range from a reprimand to the cancellation of existing grants and the declaration that individuals or even institutions are ineligible for future grants.

\section{Canadian Advisory Board \\ Ottawa}

CANADA's latest reorganization of research administration was signalled last week when the Prime Minister, Brian Mulroney, held the first meeting of the National Advisory Board on Science and Technology, which includes representatives of the Canadian scientific, business, labour and professional communities. The board, reporting directly to the prime minister, is intended as a "house of sober second thought" providing advice on science and technology policy, especially as these affect the international competitiveness of Canada's high-technology industries. Meanwhile, the draft of a comprehensive national science policy, drawn up after consultation with federal, provincial and territorial ministers, is being revised for publication in the early spring. The intention is that it should be the foundation of a "national policy action plan" to be worked out in the next two years.

C.E.

\section{New Woods Hole Director Washington}

THE trustees of the Marine Biological Laboratory at Woods Hole have elected Harlyn O. Halvorson of Brandeis University as the laboratory's new director. He will take up the post in August. Halvorson, who has been affiliated with Woods Hole since 1964, replaces J. Richard Whittaker, acting director since the retirement of Paul Weeks in October 1986. 